\title{
Analysis of the International Oil Price Fluctuations and Its Influencing Factors
}

\author{
Lingyu Yan \\ School of Earth Sciences and Resources, China University of Geosciences (Beijing), Beijing, China. \\ Email: netty_yan@126.com \\ Received February $10^{\text {th }}, 2012$; revised March $13^{\text {th }}, 2012$; accepted March $22^{\text {nd }}, 2012$
}

\begin{abstract}
Oil is one of the important strategic energy to guarantee the development of modern industry and economy, and is also an important resource, which is scrambled by each interest group in the world. Oil price fluctuation is always regarded as the barometer of worldwide economy, whose each change would be the hot issue to be concerned and discussed generally in political and economic circle in every country. This paper systematically reviewed the historical path of international oil price fluctuation, analyzed comprehensively all factors, which effect the oil price fluctuation and proposed the countermeasures and advices to respond the international oil price fluctuation. Through the analysis, this paper argues that the influencing factors are various, and with the development of the world's economy, the types of these influencing factors would increase and the influencing intensity, which presented by the various factors that affect the oil price, would also different in different historical periods.
\end{abstract}

Keywords: International Oil Price; Supply and Demand; Dollar Exchange Rate

\section{Introduction}

As a bulk commodity, which is closely linked with national economic development and the daily life of public, the yearly consumption of oil occupies about $40 \%$ of total consumption of global energy. But because of its uncertain supply and big price fluctuation, oil is a strategic fossil energy for all countries in the world. The twice widely happened oil crises in the 1970s has brought huge destructions to the worldwide economy. Since entering the 21st century, the international oil price fluctuates at a high level again, it seems that oil price has taken a rollercoaster ride, from 49.51 dollars/barrel in January, 2007 to 142.95 dollars/barrel in July, 2008, then dropped abruptly below 40 dollars/barrel in December, 2008 again. The international big oil price fluctuation has created dramatic changes for the oil and economic security in China, the major oil consuming and export country only after America [1]. Therefore, it is full of realistic directive significance to make a comprehensive and systematical review and analysis for all factors, which effect the international oil price fluctuation.

To the basic factors that decide the international oil price, some scholars believe it lies mainly in the supply and demand [2]. But in my opinion, behind the international oil price fluctuation existed not only the constantly self-adjust between supply and demand on the world crude oil market, but also the strength competition be- tween nations, for this reason caused the diversity and complexity of the factors, which effected the international oil price fluctuation. Based on this, this paper systematically reviewed first the historical path of international oil price fluctuation and summarized some basic regulars, then made a comprehensive and further analysis for all factors, which effected the international oil price fluctuation and at last made a certain prediction for the possible trend of international oil price after financial crisis based on the analysis.

\section{Historical Path of International Oil Price Fluctuation}

To analyze the international oil price, attention should be paid to the history after 1945. That's because on one hand, the oil industry before 1945 was still in its infancy, the technological level and mining capacity were far from mature, added to that a small proportion of oil consumption in the whole world energy consumption structure, which was far below the coal consumption share, the international oil price fluctuation had not big impact on the international balance of payment in the oil consumption countries; on the other hand, before the Second World War, the international oil market was leaded by several western transnational oil companies, in such a case, the oil price kept relative stability to some degree (Figure 1). 


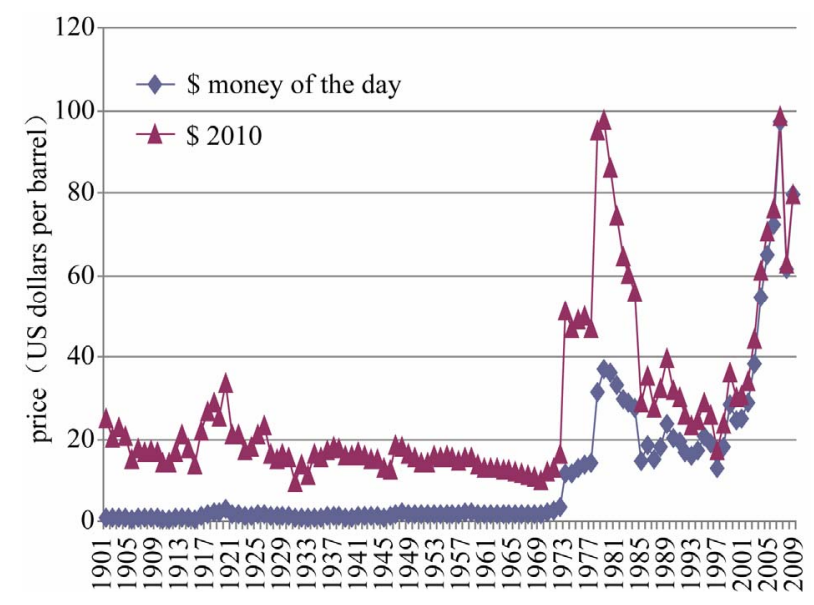

Figure 1. Crude oil price trends 1901-2010 (Source: BP, 2011).

After the Second World War, most major consumption countries entered into the full construction period, together with the improvement of technological level and mining capacity of oil industry, caused the unprecedented enthusiasm of oil demand. By 1967, the proportion of oil in the world energy consumption structure surpassed that of coal finally, reached $40.4 \%$ and become the major energy in the world. Under this background, Organization of the Petroleum Exporting Countries (OPEC) began to establish as an important organization for energy cooperation between energy exporting countries. But during this period the pricing power in the international oil market was still owned by the western transnational oil companies, the members of OPEC didn't have important impact on the international oil price at the beginning of establishment, for this reason, the oil price kept relative stability at that time. From 1948 to 1960 s, the nominal crude oil price stayed at 2.50 to 3.00 dollars. But calculated the dollars exchange rate in 2004, from 1948 to 1957, the real crude oil price fluctuated intervallic at 15 to 17 dollars/barrel and 20\% increasing was in line with inflation. From 1958 to 1970, the crude oil price dropped from 15 dollars each barrel to 13 dollars each barrel in real terms [3]. From here we could see that the international oil price was only slightly adjusted in the small scope.

As the oil production countries were exerting more and more influence on the international crude oil market day by day, the operating petroleum companies were nationalized by oil exporting countries, which was why the western oil companies gradually lost the control over the oil resources in oil producing countries. Especially in Teheran in 1971, some oil exporting countries reached a consensus to control the oil exporting through the abolishment of agreements with concession or further participating in the process of oil production or other means [4]. In the oil consumer market, since the European and
Japanese economic recovery in succession after the Second World War drove rapid growth of worldwide demands for oil and the most of them must be met by relying on the oil exporting in the Middle East, the Organization of Petroleum Exporting Countries obtained bigger words power in the international petroleum market. Plus, with the establishment of dollar standard system and dollar as the pricing currency for petroleum, dollar links officially with petroleum since the year from 1974, any country, who wants to trade oil, has to reserve dollars and since then the fluctuation of dollar exchange rate has become one of the most important factors that effect the international petroleum price.

The outbreak of fourth Middle East War in October, 1973 became the powderhose of first oil crisis and provided the members of OPEC with a perfect opportunity to recovery the oil pricing power. The Arabian oil exporting countries laid an embargo of crude oil on the countries, who were behind Israeli, and reduced the crude oil production, which finally led to the daily production reduction of crude oil of 4 million barrels in Arabian countries (From October to December, 1973, the global petroleum supply dropped by 7\%, in March, 1974, the supply was 5\% lower than that in October, 1973), and the crude oil price in the international petroleum market increased for times, 3 dollars each barrel in 1972 surged above 12 dollars each barrel at the end of 1974, and the price has remained until 1979 [3]. According to the estimation from American economists, this oil prices soaring caused economic recessions generally in western countries, the U.S. GDP growth rate dropped consequently by $4.7 \%$, the European by $2.5 \%$, the Japanese by $7 \%$.

The Iranian Revolution in November, 1978 and the Iran-Iraq War in September, 1980 resulted in the serious crippling of oil production capacity in Iran and Iraq directly. The oil-export in Iran dropped to 1 million barrels/day and by the forth quarter in 1980 the oil export was even completely stopped. The oil production in Iraq was from 3.5 million barrels/day before the war down to 500 thousand barrels/day at the end of 1980. The drastic reduction of oil production plunged the international oil market, whose clam was just restored, into a panic again, the crude oil price in spot market rose steeply with the sharp reduction of production, from 31 dollars/barrel before the war up to 40 dollars/barrel in the first ten-day period of December, which resulted in the second oil crisis. After this oil crisis the international oil price experienced a relatively long-term falling.

Until August, 2, 1990, due to the Iraqi invasion of Kuwait, the United Nations laid a total embargo of oil exporting on Iraq and Kuwait. Outbreak of Gulf War and Embargo of the United Nations led directly to daily reduction of crude oil supply by 4.7 million barrels in the international oil market, which occupied $7 \%$ of the global 
aggregate demand at that time. The following international oil price rose in as little as three months from 14 dollars each barrel to 40 dollars. However, thanks to the timely increased production in OPEC countries, the supply shortage of this oil crisis was quickly supplemented; besides the international energy institution started the emergency mechanism promptly, the member countries exchanged information and coordinated policies each other, which stabilized the market, avoided collective panic buying in the crude oil market and pulled the international oil price back quickly. So this oil crisis didn't last long and compared with the previous two crises, the fluctuation of international oil price brought by this crisis didn't have substantial impact on the world economy. After this crisis, the international oil price fell back to 15 to 20 dollars again.

After 1996, with the recovery of oil exporting and the gradual production increasing in Iraq, especially the strong impact of the Asian financial crisis on world economy and oil demand in 1997, the international petroleum price dropped continuously and fell to 10 dollars each barrel at historically low levels in 1998. OPEC appealed to underproduction continuously, which triggered a slight rebound of international oil price in 1999 and 2000, then because of the outbreak of " 9.11 " incident, the international oil price started a new round of huge increases. From 2002 on, since every country issued the tolerant economic policies in succession to boost their economic development, the global economy began to enter into a full recovery period, the global economy presented a positive state overall, the global GDP growth rate rose continuously from $2.6 \%$ in 2001 and stayed high all along. The economic resurgence brought the rapid in- creasing of crude oil demand, which caused the international oil price rose unceasingly and up to a record high price, nearly 150 dollars each barrel in the middle of the year 2008. However, because of the outbreak of financial crisis, in the second half of the year it dropped rapidly at the lowest level in recent years, to 40 dollars each barrel, by more than 100 dollars in just five months. Entering into 2009, it rose from more than 40 dollars to more than 70 dollars in short time and the increase was even up to $70 \%$.

\section{Analysis of Influencing Factors behind the Fluctuation of International Oil Price}

In accordance with the economic basic theory, price level of some commodity refers to the continuous adjustment result between the effective supply quantity and the effective demand quantity of this commodity in the market. As a special commodity, the formation of oil price should also accord with the basic laws, but because of the particularity of oil resource, in the analysis of international oil price, except considering supply and demand this basic factor, there are many other invisible factors need to be considered. On the whole, main show of the factors that affect the international oil price is in the following respects (Figure 2).

\subsection{Imbalance between Supply and Demand of Market Affects the International Oil Price}

Throughout the several big fluctuations of international oil price in the history, we can always see the existence of imbalance between supply and demand in the oil market, therefore, the relation between the oil supply and

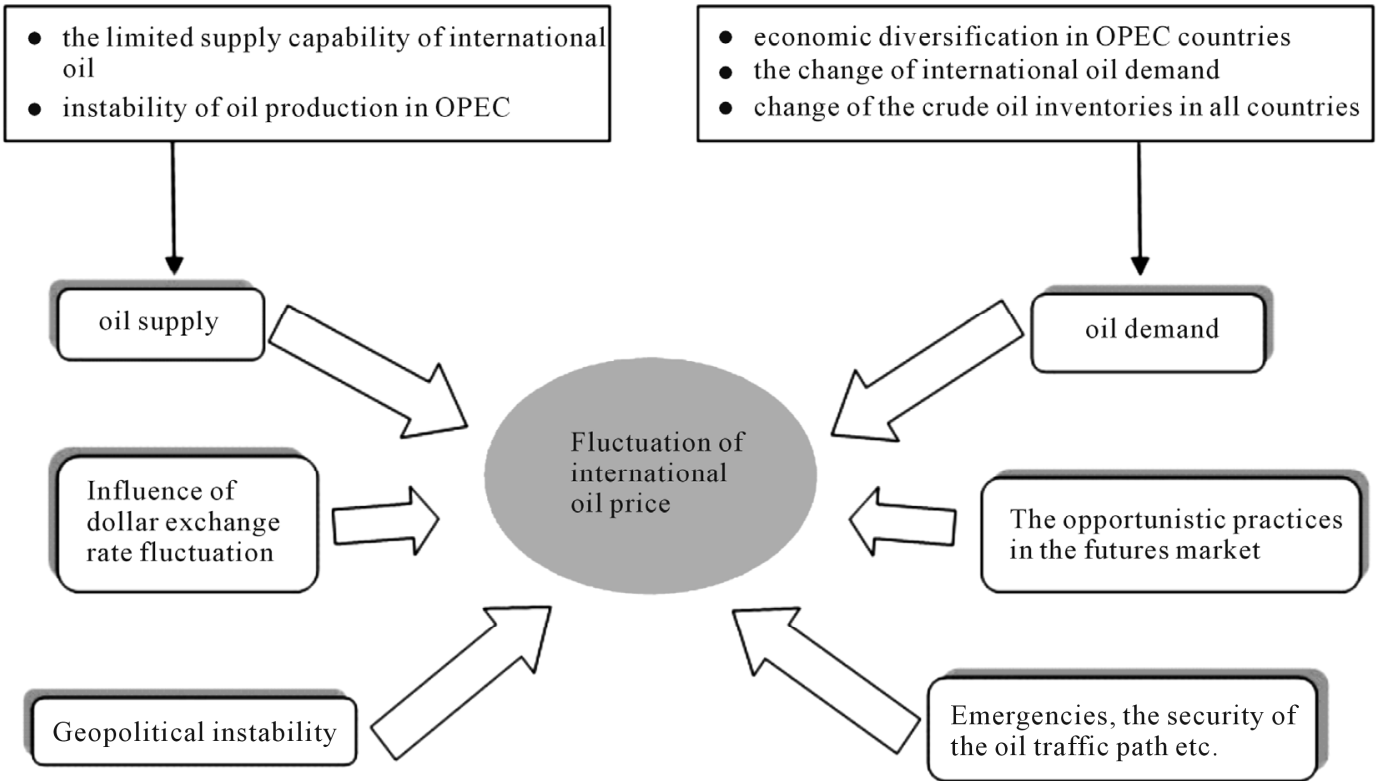

Figure 2. The influencing factors behind the fluctuation of international oil price. 
demand in the international oil market is considered as the most direct and most obvious factor that affect the international oil price, and normally, imbalance of supply and demand would easily become the powderhose of big fluctuation of international oil price.

From the perspective of oil supply, the major factors that affect the fluctuation of oil supply are due to:

1) The limited supply capability of international oil. On one hand, as a non-renewable energy the total amount of petroleum resource is limited, on the basis of a statistic, it doesn't exist newfound large oil field in recent 20 years, that's the reason why the oil proved reserves is very hard to increase substantially; on the other hand, the oil production capacity, including the capacity of exploration, development, transportation, refining, marketing and other stages, isn't increasing fast enough to keep up with the oil consumption and the capacity of production increasing in oil producing countries is obviously deficient at present; third, oil production cost would affect the supply quantity in the oil market by affecting the interperiod production allocation decisions of producers [5].

2) Instability of oil production in OPEC. Currently the oil producing countries play a more and more important role in the world energy structure and the oil consumption countries play less and less, therefore, it is widely believed by the domestic and overseas scholars that OPEC plays an important role in the factors that affect the fluctuation of international oil price. Since the members of OPEC has $75 \%$ the world's proven oil reserves, especially the oil supply of OPEC in 2004 reached $40 \%$ of the world's total oil supply, the newly increased supply occupies even $70 \%$ of the world's newly increased supply. It is such a global oil supply structure that decides OPEC plays a predominant role in the international oil market. So the policies and measures of oil production taken by this organization, the instability of underproduction and production increasing plan of OPEC would result in rapid rising of oil price and substantial improvement of risk premium. According to the quantitative analysis of the factors that affect the international oil price, which was through the concepts of cointegration and error corrective model conducted by Cheng Wei-li, the crude oil production of OPEC would have a long-term far-reaching impact on the oil price, in the long run, with each increase by $1 \%$ of production in OPEC drops the oil price by $1.23 \%$.

From the perspective of oil demand, the major factors that affect the fluctuation of international oil price are as below:

1) Economic diversification in OPEC countries. For a long time, the economic structure in OPEC countries is generally single, the petroleum industry is the most important department in the national economy and the gov- ernment's entire financial revenue relies primarily on the income brought by oil exporting, however, this single national economic structure is easily affected by the international oil market, to get rid of the overdependence on oil industry, the OPEC countries has began to formulate a series of positive measures to promote the economic diversification, while vigorously developing the oil industry and petrochemical industry, the countries begin to pay attention to the development of non-oil industries and make an effort to increase the non-oil Industrial percentage of gross domestic product. The increase of oil dollars brought by high oil price, especially before the financial crisis, contributed to enough capital owned by the OPEC countries for adjustment of economic structure, the diversification in each country achieved generally substantial results, the single economic structure was broken, the industrialization in each country accelerated. The energy industrial proportion of gross GDP in the gulf countries dropped from 38\% in 2000 to $34 \%$ in 2005, however, the non-energy industrial scale increased from 273 billion dollars to 608 billion dollars. From 1996 to 2006, the number of productive factories in six gulf countries increased from 1390 to 10431 , and the number of industrial workers increased from 110 thousand to 820 thousand [7].

With the continuous promotion of economic diversification and the continuous adjustment of domestic economic structure, the internal oil consumption in OPEC countries increased gradually, which caused that the OPEC countries become an important demand side in the international oil market. Although currently the oil demand in European Union, OECD and other western developed countries shows a downward trend gradually, but because the oil consumption in emerging market economies, especially in Middle East, Latin America and other oil exporting countries, increases rapidly, the world's oil total consumption increases constantly. Thus it can be seen that the economic diversification in OPEC countries has a significant impact on the supply and demand structure of international crude oil and an indirect impact on the trend of international oil price.

2) The supply and demand fluctuation of international oil would affect directly the change of international oil price. According to the economic theory, demand is one of the basic factors that affect the international price, thus, the fast-growing oil demand would cause the increase of oil price inevitably. While reviewing the several big fluctuations and increase of international oil price in the history, among that it is easy to see the important role the change of oil demand played. Before the outbreak of financial crisis, the global economy began to show the recovery growth since 2002, and in 2003 showed a rapid development trend, above all the development scale of traditional manufacturing industries expanded cease- 
lessly in newly industrialized countries, as is mentioned above, because of the adjustment of economic structure, the oil consumption in traditional oil exporting countries had increased, the global oil demand and consumption also had a big increase and the increase rate was far greater than that of oil supply, which caused the oil supply was more and more serious. The global economy suffered a financial crisis in the second half of the year 2008 and its development sank into stagnation, and even retrogression, under this influence, the global oil demand and consumption fell sharply and even the international oil price plummeted. For these reasons, the change of international oil demand should be considered as one of the direct factors that affect the fluctuation of international oil price.

3) Change of the crude oil inventories in all countries. Petroleum inventories include conventional inventory and unconventional inventory. Conventional inventory refers to the inventory, which can guarantee the world's petroleum production, processing and supply system normal running. And unconventional inventory refers to the commercial inventory, which is mastered by the transnational oil companies. Although the conventional inventory occupies above $80 \%$ of the global crude oil total inventory, the impact of which is far smaller than the impact of unconventional inventory on the international oil price. In the long run, as the buffering between oil supply and demand, oil inventories in all countries play a stable role on international oil price. Normally when the oil price is low, all countries increase its oil inventories generally in order to push the oil price upward; in contrast, sell the oil in store when the oil price is high, in order to push the oil price down. In the short term, oil inventory plays an important role on the fluctuation of international oil price. The oil in store is often purchased in quantity when the international oil rises, which pushes the international oil upward in a short time; the reverse is possible. Thus it can be seen that the oil inventory has a very complicated impact on the international oil price, it cannot be judged according to the same standard.

\subsection{Influence of Dollar Exchange Rate Fluctuation}

From 1974 on, dollar linked officially with oil and the most international oil trades is invoiced, delivered and settled in US dollar, thus, the fluctuation of dollar exchange rate not only has a direct impact on the stability of world's economy and international oil price in petroleum industry, but also an important impact on the oil policies in oil exporting countries and oil consumption countries and the exploration and development of world's oil. US dollar devaluation causes inevitably the rising international oil price; US appreciation brings about a drop in international oil price. On one hand, US dollar devaluation causes the actual purchasing power of oil dollar benefit of OPEC reduces greatly in the international market, thus to deal with such an emergency, the OPEC has to raise the price for losses reduction; on the other hand, US dollar devaluation improves greatly the purchasing power of other currencies, increases the attraction of crude oil futures, which exists as an investment product, to the investors in non-dollar areas, however, buying oil futures in large quantity would result in a rapid rising in international crude oil price. The quantitative analysis of the factors that affect the international oil price, which conducted by Cheng Wei-li indicates that, both in the long term and the short term, the fluctuation of dollar exchange rate would affect the international oil price, in the long run, with each increase of dollar exchange rate by $1 \%$ drops the oil price by $3.06 \%$; in the short run, with each increase of dollar exchange rate by $1 \%$ drops the international oil price by $1.82 \%$.

The most oil exporting countries regard dollar as the settlement currency of crude oil export, while pay the importing goods from Europe in euro, the change of exchange rate between dollar and euro causes directly that the exporting cost in major oil producing countries increases, thereby causes indirectly the aggravation of domestic inflationary. Therefore, many experts indicate that dollar devaluation is the proximate cause of the continuous rising of international oil price, of which the dollareuro exchange rate weakness is the major cause [8].

Within the US, because the big dollar devaluation can ease the US government's debt crisis effectively, cut the whopping budget deficit, fit the import of foreign goods while driving the American export effectively, from the end of 2001, the exchange rate of dollar against the western major currencies dropped by more than $15 \%$, at the same time the international oil price rose nearly five times. In 2007 a year, the exchange rate of dollar to euro dropped more than $10 \%$, the international crude oil price at the same time rose by above $60 \%$. Thus it can be seen that dollar devaluation plays an important role on the spurt in international oil price at that time. The whopping financial and trade deficit after the financial crisis, with that the US is faced, can not be changed qualitatively in the short term, so it is predicted that in the next period the dollar exchange rate will remain in the doldrums for a long time and the international oil price will also hover in the high.

\subsection{Geopolitical Instability}

Since the current proven reserves of petroleum concentrate in the so called "Heart of the world's supply", the oil-rich areas, from Maghreb to the Persian Gulf, to the 
Caspian Sea, extending to the Transcaucasia, Siberia, and the reserves of which occupies $65 \%$ of the global oil reserves, the stability problem in oil producing areas affects directly the supply in the international oil market, thereby indirectly the international oil price. By reviewing the fluctuation path of the international oil price since the last century, it is not hard to see that the trend of international oil price links always closely with the political situation in the oil producing areas. Currently the geopolitical risk exists still in the Middle East and other oil producing areas, for example, as the fourth oil exporting country in the world, Iran possesses 18.9 billion tons oil proven reserves, which occupies $11.4 \%$ of the world's, reserve and production ratio is 86.7 , the daily oil production is 4000 thousand barrels, the yearly oil export is about 120 million tons, however, its nuclear project remains still in suspense, add to that the relation between Iran and the western especially America remains always in the tension state, so the nuclear issue is always a serious and unstable factor for the current international oil market, the longer time it take to solve the Iranian nuclear issue, the greater impact on the international oil price. Besides, Turkish troops crossed the border and attacked the PKK forces in northern Iraq, which threatens the oil production and exporting in Iraq, the oil disputation between Russia and Belarus, the Venezuela's uncooperative attitude to the American oil supply, and in the Africa's major oil-producing country Nigeria, the incidents that the petroleum installations and oil workers were attacked happened for many times, all these aggravate the concern of the crude oil supply. It is widely believed by the analyst that in the future he international oil market will become more and more sensitive to the geopolitical risk.

\subsection{The Opportunistic Practices in the Futures Market}

The spot oil price in the current international oil market is not directly decided by the supply and demand sides, the two sides confirm normally some kind of valuation formula while concluding and signing the supply contracts and the benchmark price of this valuation formula links generally directly with the oil price in the oil futures market, thus, price of the international oil futures affects the spot oil price to a great degree and is considered as the pointer of the spot oil price, this unique oil price formulation mechanism decides that the oil price would be affected inevitably by the opportunistic factors of futures market. Since November, 2003, the long opportunistic trades in the NYMEX are always bigger than the short, the speculative factors aggravate the growth of oil price. The report of CFTC on 7th, October, 2004 indicated that since the middle of September, the net-long position had increased by 24,000 , which was in accordance with the growth of oil price, this suggests that the role, played by the opportunistic factors in the futures market, on driving the growth of oil price can not be underestimated [6].

Thus, the oil speculative practices have been one of the important factors to the instability of international oil market and aggravated the turmoil in the international oil market. With the gradual growth of international oil price, the huge international capital enter into the trading market of crude oil futures, the investment organizations hype expectedly the oil futures through imbalance between supply and demand or by utilizing the asymmetric of the market information purchase the oil futures contracts in quantity yet without real possession of oil, which creates the whopping virtual oil demand. The research of OPEC indicates that the global current daily consumption of crude oil is about 87 million barrels, however, the trading volume of financial products related with petroleum is up to 1.36 billion barrels. With the double growth of the oil demand in the futures market, the oil price in the futures market would rise inevitably. Therefore, the speculative practices in the international oil futures market are often the perpetrators who control the big fluctuation of international oil price in the short run. But due to the structural characteristics of futures market itself and the restrictions and constraints in the aspect of the crude oil futures trading supervision, oil opportunistic practices can only affect the international oil price in the short run and can't decide the long-term trend and level of the international oil price yet.

\subsection{Other Influencing Factors}

Except having the common properties of commodity, petroleum has also the property of strategic supplies. Thus, its price is affected not only by the supply and demand and other market factors, but also by emergencies, climate change and other factors to a great degree.

On the basis of the difference of process, nature and mechanism of emergencies, the public emergencies, which could affect the fluctuation of international oil price, can be divided into three major types: 1) wars and politic disturbances; 2) social security incidents, includeing terrorist attack incidents, economic security incidents, foreign involved emergencies; 3) natural calamities, refer mainly to meteorological disasters, geological disasters etc. [9]. On one hand, emergencies affect directly the actual oil supply and demand; on the other hand, they affect people's psychological expectation of the future international oil market, thereby have an indirect impact on the international oil price. Because different types of emergencies have different impact on the fluctuation of crude oil price, we should make the specific analysis 
combined with the incident nature and the total economic conditions at that time. For example, the American hurricane Katrina, happened in August, 2005, occurred and hit the American Mexico gulf states and made the petroleum installations of about $25 \%$ oil production in America suffer from the serious damages, the refineries, whose oil refining capacity occupies about $10 \%$ of the whole America's, had to close, which resulted in the daily reduction of 1.5 million barrels crude oil and 2 million barrels refined oil and affected directly the tension supply of crude oil and refined oil in the international oil market. Add to that because it was a huge natural disaster happened in the American mainland, it brought about traumas in American public and also a pessimist economic expectation, consequently affected the violent shake of the international oil market and caused the rapid growth of the international oil price [10]. However, the "9.11" terrorist attack incident in 2001 caused the turmoil and panic of the international oil market by affecting the people's psychology [11]. But the emergencies play normally an important role on the fluctuation of international oil price just for a short time, in the long run, it would not have a big impact on the oil trend.

Besides, because the oil and gas resource in the world distribute extremely in unbalance, nearly $2 / 3$ oil needs to be transported through some important straits, canals or pipe laying. For example, nearly half of the global oiltankers need to pass through the Strait of Malacca. Thus, the security of the oil traffic path would also have an important impact on the international oil price in the short run.

\section{Conclusions}

By reviewing the historical path of the international oil price fluctuation, it is not difficult to see that due to the special properties of oneself and the strategic significance, the factors that affect its fluctuation are various (including not only the supply and demand and other traditional market factors, but also implies the competetion between all the world's economic entities), and with the development of the world's economy, the types of these influencing factors would increase and the influencing intensity, which presented by the various factors that affect the oil price, would also different in different historical periods. Since the fluctuation of one or more factors would affect the international oil price, the diversity and the complexity of the influencing factors of international oil price increase the difficulty to predict the international oil trend [5].

The drastic fluctuation of international oil price would cause great damages to the economy of China, the second largest oil consumer and the third oil importing country in the world. Although the continuous increase of crude oil import and consumption in our country is affecting the international oil-price trend gradually, yet restricted by the crude oil pricing mechanism, our country can only accept the international oil-price passively in a short time, therefore, the international oil-price growth would inevitably increase the cost of oil import in our country. In order to avoid the adverse impacts of our country's economy caused by the international oil-price fluctuation, from my perspective, China should take multi-pronged response options. On one hand, improve the oil utilization ratio through technological innovation and promotion of alternative energy source and promote the establishment of energy diversification, and then reduce the dependence on oil. On the other hand, while accelerating the system building of national petroleum reserves and petroleum security emergency and perfecting the petroleum reserves system, invest actively the overseas energy development, intensify the cooperation with the major oil producing countries in the world, invest the oil fields in the major oil producing countries, master the initiative of crude oil supply.

Third, our country should take it into account that encourage more domestic companies to participate in the international oil futures market more actively, so as to spread risk and lock in costs; meanwhile further develop the oil futures market in our country itself, form our oil quotation system, and then affect the international oil market and the international oil price.

\section{Acknowledgements}

This work was financially supported by Key Project of “12th Five-Year” National Key Technology (2010BAB 04B06), Project of Ministry of Land and public service sectors (201111007-4).

\section{REFERENCES}

[1] J. Lin, A. J. Wang, W. J. Yu and Y. Zhou, “The Impacts of Oil Futures Market Mechanism on Chinese Oil Security,” Acta Geoscientica Sinica, Vol. 5, 2010, p. 693.

[2] W. Du, "The Determinant and the Future Trend of International Oil Price," Economic Theory and Business Management, Vol. 9, 2006, p. 70.

[3] Q. Y. Guan, "The Period Model and Policies of the Fluctuation of International Oil Price," International Petroleum Economics, Vol. 1, 2008, p. 26.

[4] R. O. Keohane, "After Hegemony: Cooperation and Discord in the World Political Economy," Princeton University Press, Princeton, 1984.

[5] Y. B. Zhang, "Analysis of Influencing Factors of International Oil Price,” Chinese Petroleum Enterprise, Vol. 3 2008, p. 96.

[6] W. L. Cheng, "Quantitative Analysis of Influencing Factors of International Oil Price,” International Petroleum Economics, Vol. 8, 2005, p. 40.

[7] Z. W. Zhao, "The Long-Term Impacts of Economic Di- 
versification in OPEC on International Oil Price,” Economic Review, Vol. 2, 2009, p. 79.

[8] B. X. Ji and T. Song, "Discussion of the Reasons and Response Options of the Sharply Rising of International Oil Price,” Journal of Chongqing Normal University Edition of Social Sciences, Vol. 3, 2009, p. 109.

[9] S. Q. Wang, Y. Chen and Y. J. Jin, “Analysis of the Impacts of Emergencies on International Oil Price," Mathmatics in Practice and Theory, Vol. 9, 2009, p. 88.
[10] B. W. Cashell and M. Labonte, "The Macroeconomic Effects of Hurricane Katrina, Report for Congress,” 2005. http://fpc.state.gov/documents/organization/53572.pdf

[11] G. Makinen, “The Economic Effects of 9/11: A Retrospective Assessment,” 2002. http://www.fas.org/irp/crs/RL31617.pdf

[12] BP, “BP Statistical Review of World Energy,” 2011. http://www.bp.com/statisticalreview 